\title{
Comparison of Irrigation Automation Algorithms for Drip-Irrigated Apple Trees
}

\author{
Yasin Osroosh ${ }^{\text {a, }}$, Robert Troy Peters a, Colin S. Campbell b, Qin Zhang a \\ ${ }^{\text {a }}$ Center for Precision \& Automated Agricultural Systems, Washington State University, United States

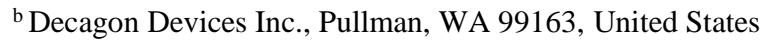

\begin{abstract}
Seven irrigation scheduling algorithms and an automatic control system along with a wireless network of soil, thermal and weather sensors were developed and assessed in Prosser, WA in the growing season of 2013. The system was comprised of six wireless sensor and valve actuating nodes installed across an apple orchard, a central base station made up of a transceiver connected to a laptop, and a graphical user interface (GUI). The irrigation algorithms/treatments included the time-temperature threshold (TTT), crop water stress index with dynamic threshold (CWSI), soil-based using granular matrix sensors (SOIL), weather-based using a temperature-only-based evapotranspiration (ET) model and soil water balance (WB), a combination of SOIL and WB $(\mathrm{SL}+\mathrm{WB})$, a conventional irrigation practice used in the region (CNTRL), and soil-based using a neutron probe (NP) as benchmark. Different treatments were compared based on the total irrigation water $\left(I_{t}\right)$ applied during the season. They were also compared based on simplicity and expense for a grower to implement. Soil water content $\left(\theta_{S}\right)$ and stem water potential $\left(\psi_{\text {stem }}\right)$ were monitored in a number of treatment plots. The total applied water for CNTRL was significantly higher than all other treatments $(p<0.001)$. The thermal-based TTT and CWSI treatments applied the same amount of water as NP and WB $(p<0.001)$. CWSI and TTT substantially reduced water applied (70\%) while maintaining $\psi_{\text {stem }}$ within the non-stressed range. In addition, $\theta_{s}$ in the treatment plots of TTT and CWSI did not exceed the maximum allowed deficit recommended for apple trees (MAD of 50\%) showing a strong agreement with NP. The SOIL and SL+WB treatments resulted in tangible under-irrigation as leaf drop, decreased leaf turgidity, growth reduction and abnormally small fruits were seen. Among all the strategies, WB seemed to bear the characteristics of being economical, easy to implement and fairly accurate. Our preliminary results also support the use of wireless sensor network for automatic irrigation management of drip-irrigated apple trees.
\end{abstract}

Keywords: Wireless sensor network, plant-based approach, automatic irrigation scheduling, thermal sensing, drip irrigation

${ }^{1}$ Corresponding author. E-mail address: yosroosh@gmail.com (Y. Osroosh)

(C) 2016. This manuscript version is made available under the Elsevier user license http://www.elsevier.com/open-access/userlicense/1.0/ 


\section{Introduction}

A sound choice of irrigation scheduling method can lead to increased profit and water savings for farmers, reduced environmental impacts and sustainable agriculture (Smith et al., 1996). Proper management of irrigation water to maintain balanced soil water content is crucial for health and productivity of apple trees (Black et al., 2008). To date, research has offered a large number of approaches to detect water stress, compute crop water needs, and automatically schedule irrigation (Al-Kaisi et al., 1997; Orta et al., 2003; Jones, 2004; Farahani et al., 2007; Vellidis et al., 2008; McCready et al., 2009; Ko and Piccinni, 2009; Migliaccio et al., 2010; Romero et al., 2012). Irrigation scheduling approaches may be grouped into three main categories (Zhang and Francis, 2013): i) monitoring of soil water status (soil-based), ii) soil water balance calculations using weather information (weather-based), and iii) sensing of crop water stress (plant-based).

Automation of irrigation has been evaluated in a number of row plants including tomato, onion and bell pepper using soil sensors measuring tension (Thompson et al., 2007; Enciso et al., 2009) or volumetric water content (Zotarelli et al., 2009). Vellidis et al. (2008) developed and evaluated a real-time, smart soil moisture and temperature sensor array prototype for scheduling irrigation in cotton. Romero et al. (2012) reported that the approach of combining weather data with soil moisture signal could increase irrigation efficiency in almond trees. Tensiometers have been used by Meron et al. (2001) as a feedback to manage irrigation of apple trees. Soil water tension sensors provide a

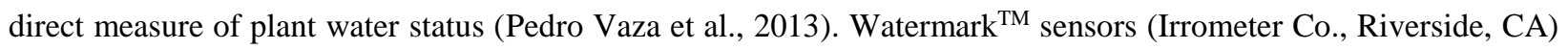
have been identified as good indicators of irrigation start and stop (Leib and Matthews, 1999); however, sensor accuracy is contingent to site-specific calibration (Varble and Chávez, 2011). The calibration need of individual sensors can make the use of Watermark ${ }^{\mathrm{TM}}$ sensors tedious and unattractive to most farmers, thus very often they are used with only factory calibration. Neutron probe is a scientific-based method for precise measurement of soil water content and has shown to be a reliable reference for other irrigation scheduling techniques (Evett et al., 2009; O’Shaughnessy et al., 2012b).

How change in weather parameters can affect plant water needs can be predicted using an evapotranspiration (ET) model. Frequently used ET models are the Penman-Monteith (PM) (Allen et. al, 1998) and Hargreaves (Hargreaves and Samani, 1985) equations. The Hargreaves model requires fewer data than the PM model and can provide estimations of ET using air temperature as sole input (Allen et al., 1998). The most common approach to 
estimate actual water use of apple trees $\left(\mathrm{ET}_{\mathrm{c}}\right)$ is to multiply the reference $\mathrm{ET}\left(\mathrm{ET}_{\mathrm{r}}\right)$ by a crop-specific coefficient $\left(\mathrm{K}_{\mathrm{c}}\right)$ (Lakso, 2003). Osroosh et al. (2014, 2015a) developed models based on infrared thermometry and the energy budget of a single apple leaf to estimate the actual and potential transpiration of whole tree. However, like the PM model, they require a wide range of input data. The weather-based irrigation scheduling has a long history of implementation using commercial irrigation controllers for both research (Davis et al., 2009; Davis and Dukes, 2010; CardenasLailhacar et al., 2008, 2010) and commercial applications; however, few research studies have investigated its application on fruit trees. In a study by Kisekka et al. (2010), ET-based irrigation scheduling saved significant quantities of water compared with a calendar-based grower's approach of irrigation in a Carambola Orchard.

Leaf water potential measured using a pressure bomb has long been used to monitor crop water status and as trigger point for irrigation (Stegman et al., 1976; Turner, 1988). However, this method is very tedious, labor-intensive and not appropriate for automation. The use of infrared temperature of plant canopies along with a number of ancillary meteorological measurements is an alternative plant-based approach (Cohen et al., 2005). Irrigation scheduling systems based on a feedback from crop have shown to outperform scientific-based irrigation scheduling using the neutron probe in row crops (O’Shaughnessy et al., 2015). Various thermal-based scheduling algorithms have been developed such as the crop water stress index (CWSI: Jackson et al., 1981, 1988) and time-temperature threshold (TTT: Wanjura et al., 1992, 1995; Upchurch et al., 1996). CWSI compares the measured canopy-air temperature differences $\left(\Delta T_{m}\right)$ with theoretically/empirically determined temperature differences of a non-transpiring $\left(\Delta T_{u}\right)$ and well-watered $\left(\Delta T_{l}\right)$ plants as defined by Idso et al. (1981):

$$
C W S I=\frac{\Delta T_{m}-\Delta T_{l}}{\Delta T_{u}-\Delta T_{l}}
$$

Different varieties of the CWSI have been suggested over the years including the CWSI and time threshold (CWSI-TT: O’Shaughnessy et al., 2012b), integrated CWSI (iCWSI: O’Shaughnessy et al., 2013) and CWSI-DT (Osroosh et al., 2015b). CWSI has been rarely used to schedule irrigation in trees (Osroosh et al., 2015b) and more often to detect water stress (Testi et al. 2008; Wang and Gartung, 2010; Paltineanu et. al. 2013; Agam et al., 2013; Berni et al., 2009; Osroosh et al., 2016). The CWSI might be affected by many unwanted factors such as dust or passing clouds (O'Shaughnessy et al., 2012b); however, it has proven to be reliable if integrated into a robust algorithm which account for these temporary conditions (Osroosh et al., 2015b).

The TTT method, also patented as "BIOTIC", requires a "time threshold" and a "temperature threshold." The temperature threshold is the optimal leaf temperature for enzyme activity determined in lab. The time threshold is the 
accumulated time above the temperature threshold for non-stressed crop in specific climate calculated using experimental/simulated data. O'Shaughnessy and Evett (2010) carried out automatic irrigation experiments on cotton using the TTT algorithm in Texas. Peters and Evett (2008) used the TTT method to automate water delivery to the center pivot-irrigated plots of soybean. To our knowledge, no reports are available on irrigation scheduling of woody fruit trees using the TTT approach.

Nowadays, some growers rely on wireless sensor networks (WSN) to obtain information remotely on a wide range of parameters but rarely to automatically schedule irrigations (O'Shaughnessy et al., 2013). In research, WSNs have been employed to collect weather, soil and environmental information using soil moisture, temperature, or agrometeorological sensors, and to control a variety of irrigation systems (Coates and Delwiche; 2009; Kim et al., 2009; O'Shaughnessy et al., 2015; Ojha et al., 2015). A site-specific irrigation control system uses a WSN to monitor field variables and minimize the spatial variability of irrigation. In order to make the wireless technology available to growers, Coates et al. (2013) developed and integrated a valve actuation system with a commercially-available WSN. Both wired and wireless sensors network systems have been used in automatic irrigation scheduling (Peters and Evett, 2008; O'Shaughnessy and Evett, 2010; O’Shaughnessy et al., 2012a; O’Shaughnessy et al., 2013) with the later being more flexible, convenient and economical.

Besides reducing labor requirements, automatic software scheduling tools are necessary for optimizing the amount of irrigation water in response to crop development and type, and environmental conditions (Casadesús et al., 2012). The software must be user-friendly and allow for simple management of the WSN and irrigation valves by growers (Kim and Evans, 2009). Various computer software packages have been developed for monitoring soil parameters and irrigation scheduling over a wide range of irrigation systems (Stone et al., 1985; Hess, 1996; Abreu and Pereira, 2002). Kim and Evans (2009) developed decision support software to collect information from a WSN and control a site-specific linear-move irrigation system on a malting barley field.

The aforementioned approaches have been widely used in research; however, farmers are still far from adopting them. They are eager to see reliable irrigation scheduling methods which are affordable and not necessarily complicated, yet accurate and suit their field and crop conditions. Our specific objectives here were to i) develop fully automatic irrigation supervisory control and data acquisition (SCADA) system, and wireless sensor network, ii) develop computer soil-, plant-, and weather-based algorithms for scheduling irrigation of drip-irrigated apple trees, iii) collect information on these various strategies in terms of total amount of water applied, root zone soil water status 
(content/tension), plant water status (stem water potential), cost and simplicity. This paper emphasizes on the plantbased approaches and presents the results of a preliminary field evaluation in a growing season in the arid region of central Washington.

\section{Materials and methods}

\section{Study area and irrigation system}

The study was conducted in a Fuji apple orchard on the Roza Farm of the Washington State University Irrigated Agriculture Research and Extension Center near Prosser, WA $\left(46.26^{\circ} \mathrm{N}, 119.74^{\circ} \mathrm{W}\right)$ during the irrigation period of 2013. The region was semi-arid with an average annual precipitation of $217 \mathrm{~mm}$ and little summer rainfall. The site's soil was Warden Silt Loam, 1-m deep limited by a rocky layer to shallower depths in some plots. The average volumetric water content at field capacity, $\theta_{F C}$, was $0.33 \mathrm{~m}^{3} \mathrm{~m}^{-3}$ measured as drained soil water content after a heavy irrigation event. The trees were spaced $4 m$ (row spacing) by $2.5 m$ (tree spacing) apart. In 2007, the trees were irrigated with a micro-sprinkler irrigation system (Hurricane, NaanDanJain Irrigation Ltd., Post Naan, Israel) with water emitters of $27 \mathrm{Lh}^{-1}$ spaced at $2.5 \mathrm{~m}$ intervals. In 2013, the irrigation system was drip tubing with two lines of pressure compensating laterals $\left(\sim 0.6 \mathrm{~m}\right.$ apart) of in-line $2.0 \mathrm{Lh}^{-1}$ (equivalent to $1.1 \mathrm{mmh}^{-1}$ ) drippers (BlueLine® PC, The Toro Company, El Cajon, CA), spaced at $91.4 \mathrm{~cm}$ intervals along the laterals. In 2013, the irrigation system was configured for twenty one irrigation zones (discussed later) and flow to each zone was controlled with a latching solenoid valve (LSV) (Irritrol, Riverside, CA). A conservative value of $85 \%$ was assumed for the efficiency of the irrigation system.

\section{Wireless control and monitoring system}

A wireless control and monitoring system was developed to take measurements from in-field sensors and control the on/off time of LSVs to create zone-specific irrigation rates in the orchard (Fig. 1). The system was comprised of two main components: 1) central base station (master) including a laptop computer and graphical user interface (GUI), and 2) six slave wireless nodes (sensing and valve actuation stations). The laptop was located in a room only $50 \mathrm{~m}$ far from the field. A laptop cooling pad and a backup battery were used to cope with room's high temperature during the hot summer and unexpected power blackouts, respectively. The base station also consisted of a $900 \mathrm{MHz}$ spread 
spectrum radio (model RF401, Campbell Scientific, Logan, UT) to communicate with the nodes, and a USB mobile broadband stick (model DataJack, Inc., Dallas, TX) to provide internet access. Irrigation control was managed by the base station using the GUI developed by the authors (discussed later).

A wireless node was made up of a datalogger (model CR10(X), Campbell Scientific, Logan, UT), $900 \mathrm{MHz}$ spread spectrum radio (model RF401, Campbell Scientific, Logan, UT) with $3 \mathrm{dBi}$ omni-directional rubber-duck antenna (L-COM Inc., North Andover, MA) to transmit data to and receive control signals from the base, $10 \mathrm{~W}$ solar panel (model SYP105, Instapark Co., Santa Fe Springs, CA) including voltage regulator, and $12 \mathrm{~V}, 7 \mathrm{Ah}$ sealed lead acid battery. Each node controlled up to four LSVs operated by two L298 dual H-bridge motor drives (Robotshop Inc., Mirabel, Quebec).

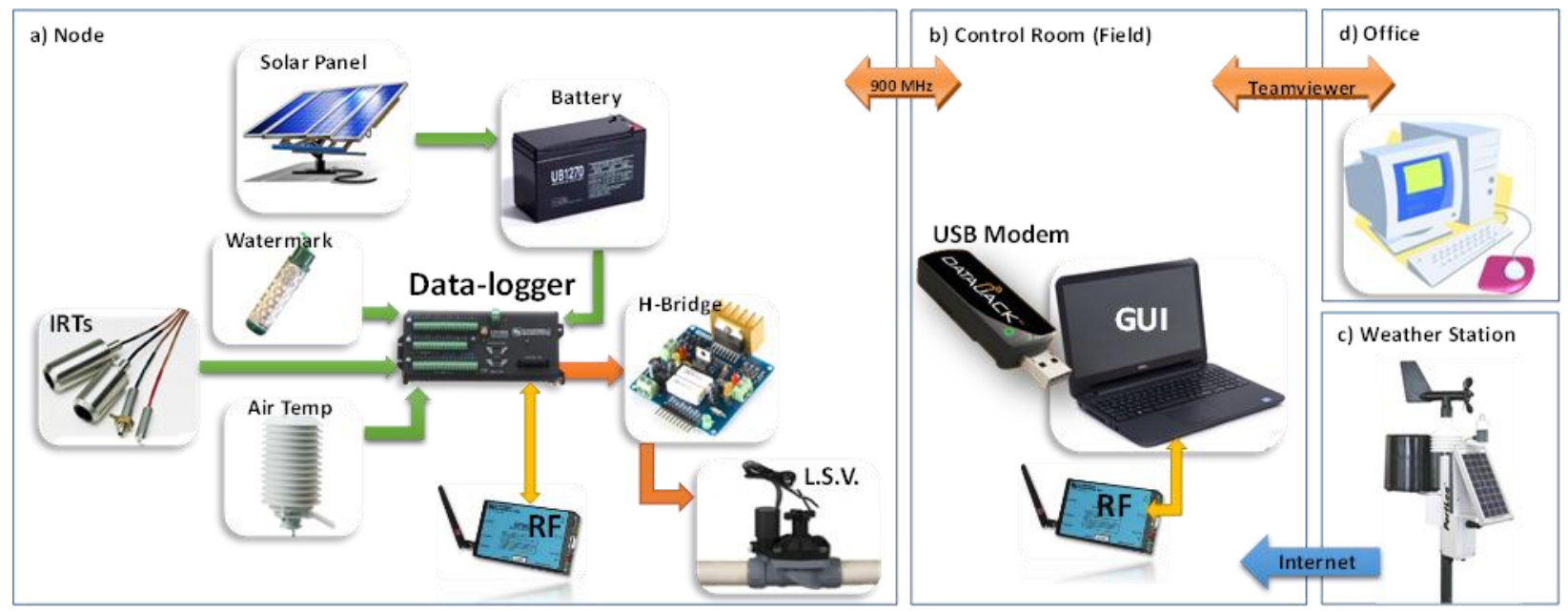

Figure 1. Components of the wireless control and monitoring system: a typical wireless node (a), base laptop and graphical user interface (GUI) (b), and weather station (c). The GUI was accessed by the office computer using the Teamviewer software (d). A sensing and valve actuating node included all or some of the following sensors and components: CR10(X) datalogger, solar panel, battery, Watermark ${ }^{\mathrm{TM}}$ sensors, infrared thermometers (IRTs), shielded air temperature probe (Air Temp), $900 \mathrm{MHz}$ spread spectrum radio (RF), H-bridge and latching solenoid valve (LSV). The base control was made up of a laptop computer, dongle (USB modem) and RF.

Nodes were also taking readings from a number of in-field sensors including granular matrix sensors (model Watermark 200SS, Irrometer Co., Riverside, CA), a soil temperature sensor (Model 107, Campbell Scientific, Logan, UT), shielded air temperature sensors (Model 109, Campbell Scientific, Logan, UT), and industrial thermocouple infrared thermometers (model IRT/c.2: Type J, Exergen, Watertown, MA) with a field view of $35^{\circ}$ and $\pm 0.6^{\circ} \mathrm{C}$ absolute accuracy. Depending on its location in the orchard, a node was comprised of all or only some of the aforementioned 
sensors. The furthest sensing and valve actuating station/node was located about $150 \mathrm{~m}$ far from the central base radio. The in-field sensors were scanned/sampled by the node dataloggers every $5 \mathrm{sec}$ and averaged every $15 \mathrm{~min}$. The collected data by the nodes were then retrieved by the GUI every 15 min and time stamped.

\section{Sensor installation and field measurements}

The air temperature probes were installed at a height of $2 \mathrm{~m}$ (in-line with trees). It is known that the rooting depth of a mature apple tree is about 70-90 cm (Atkinson, 1980) and soil water content measurements should take place from about 10 (cultivation depth) to $60 \mathrm{~cm}$ (0.7 times effective depth of rooting) (Black et al., 2008). Taking this into consideration, the soil temperature probe and Watermark ${ }^{\mathrm{TM}}$ sensors were installed horizontally at a depth of $30 \mathrm{~cm}$ placed between the drip tubing laterals about $\sim 1.25 \mathrm{~m}$ from tree trunk. The Watermark ${ }^{\mathrm{TM}}$ sensors were soaked in water for two days and then installed in a soil wetted to near saturation. All the sensors were installed at the center of plots. The near real-time agro-meteorological data (air temperature, solar radiation, relative humidity, wind speed, and rainfall) measured at Roza weather station (located about $0.5 \mathrm{~km}$ away from the orchard) was pulled from the Washington State AgWeatherNet website. This data was used to calculate daily $E T_{r}$ and provided the supplementary measurements for the CWSI and TTT algorithms (discussed later).

Midday Stem water potential $\left(\Psi_{\text {stem }}\right)$ was measured with a pressure bomb (Model 615, PMS Instrument Co., Albany, OR) once per week between 13:00 and 15:00. A total of six $\Psi_{\text {stem }}$ readings (two readings per zone/plot per sampling day) were averaged to calculate mean $\Psi_{\text {stem }}$ corresponding to a treatment. Soil water content was measured with a field-calibrated neutron probe (503DR Hydroprobe, Campbell Pacific Nuclear, Concord, CA) on a weekly basis. Soil moisture and $\Psi_{\text {stem }}$ measurements took place in the plots under the plant-based treatments (CWSI and TTT). An irrigation treatment was managed using the neutron probe (discussed later). The IRT installation methods, neutron probe calibration, and $\Psi_{\text {stem }}$ measurement procedure were similar to those described by Osroosh et al. (2015b).

\section{Irrigation scheduling algorithms}

The computer algorithms required for implementing seven different irrigation treatments were developed based on main plant-, soil- and weather-based irrigation scheduling approaches and included feedback and feed-forward control strategies. The irrigation scheduling treatments were 1) a soil water budget model using a temperature-only- 
based ET equation (WB), 2) Watermark ${ }^{\mathrm{TM}}$ soil water tension sensor (SOIL), 3) a combination of WB and SOIL algorithms $(\mathrm{SL}+\mathrm{WB}), 4)$ the scientific-based method of using neutron probe (NP), 5) Canopy temperature signal and the TTT method (TTT), 6) Canopy temperature signal and the CWSI-DT method (CWSI), and 7) conventional irrigation scheduling method in the region (CNTRL). All the strategies were completely automatic except for NP in which soil moisture data collected manually. The main required inputs to the algorithms were canopy temperature (infrared) to determine crop water status, soil water tension to measure soil water availability, and meteorological data to estimate daily water needs using ET model and to calculate theoretical CWSI. These algorithm are describe in the following paragraphs.

\section{Soil water budget model and a temperature-only-based ET equation (WB)}

The algorithm was established on a simple soil water balance (Dukes and Shedd, 2009) and daily estimations of reference $E T\left(E T_{r}\right)$ using the Hargreaves model (Hargreaves and Samani, 1985). Reference ET was adjusted by local crop coefficients $\left(K_{c}\right.$; Karimi et al., 2013) interpolated for daily values. Daily (net) irrigation water depth $\left(I_{d}, \mathrm{~mm}\right)$ was calculated as the following:

$$
I_{d}=E T_{c}-R_{e}
$$

where $R_{e}$ is effective rainfall, and $E T_{c}$ is the crop $E T\left(E T_{c}=K_{c} E T_{r}\right)$, all in units of $m m$. $E T_{c}$ was determined at midnight using 24- $h$ air temperature data obtained from sensors installed in the orchard. For simplification, the effective rainfall was assumed to be equal to the amount of rainfall from the nearby weather station. The difference between soil water content at the beginning of the season $\left(\theta_{i}\right)$ and soil water content at field capacity $\left(\theta_{F C}\right)$ was added to the irrigation depth in the first irrigation event. ET was calculated using the FAO-56 Hargreaves equation (Allen et al., 1998). Twenty years worth of historical weather data and the ASCE Standardized PM equation (Allen et al., 2005) were used to calibrate the Hargreaves model for the region.

Given that the drip system had a very low discharge rate, a threshold $\left(I_{t h}\right)$ was set for irrigation depth. This guaranteed the amount of water applied was enough to wet the whole root zone and yet avoid deep percolation. The irrigation water depth per application day was calculated according to the following model:

$$
I=\left\{\begin{array}{cl}
I_{d} & \text { if } I_{d} \geq I_{t h} \\
\sum I_{d} & \text { otherwise }
\end{array}\right\}
$$


The accumulated depth over several consecutive days had to exceed the threshold in order for the system to schedule an irrigation event.

\section{Soil-based irrigation using Watermark ${ }^{T M}$ sensor (SOIL)}

This irrigation scheduling algorithm (Fig. 2a) was developed based on soil water potential readings from a Watermark ${ }^{\mathrm{TM}}$ sensor (one sensor per plot), and dry (50\% depletion) and wet (field capacity) thresholds of -80 and -30 $k P a$, respectively, recommended for the soil type (Black et al., 2008). The field soil was assumed to be homogenous. Previous studies in a drip-irrigated soil have shown that the overall water status can be reliably extracted from single spot measurements (Rolston et al., 1991). An irrigation event was automatically scheduled whenever soil water potential exceeded the dry threshold and stopped if it reached the wet threshold. Therefore, the amount of applied water was dependent on the time when the wet threshold was reached.
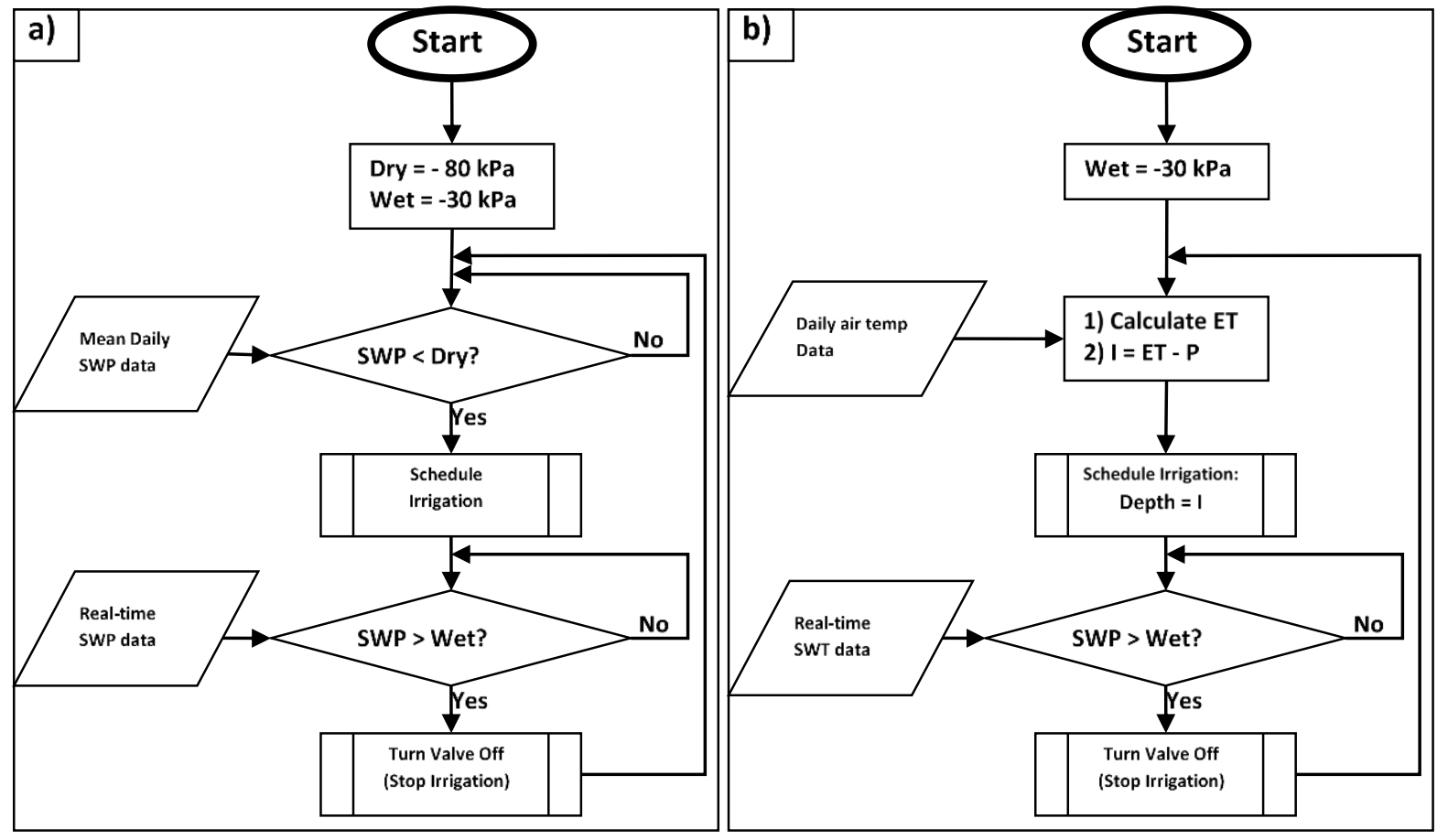

Figure 2. Soil-based irrigation scheduling algorithm (SOIL) (a), and combined Watermark ${ }^{\mathrm{TM}}$ and water budget irrigation scheduling algorithm (SL+WB) (b). 
Varble and Chávez (2011) showed that diurnal soil temperature fluctuations could impact readings of Watermark $^{\mathrm{TM}}$ sensor. A non-linear temperature compensation formula (Thompson and Armstrong, 1987) was applied to resistivity readings as the following:

$$
P_{S W}=\frac{R_{S}}{0.01306\left[1.062\left(34.21-T_{s}+0.01060 T_{s}^{2}\right)-R_{S}\right]}
$$

where $R_{S}$ is the measured resistance $(\mathrm{kOhm}), T_{s}$ is the soil temperature $\left({ }^{\circ} \mathrm{C}\right)$, and $P_{S W}$ is the soil water potential $(\mathrm{kPa})$. We did not field-calibrate the sensors for the soil type to comply with the common approach and ease the use of the sensors.

\section{Combination of WB and SOIL $(S L+W B)$}

This algorithm was the combination of the WB and SOIL algorithms similar to the algorithm proposed by Casadesús et al. (2012). SL+WB combines a compensating mechanism (feedback control) based on soil sensor readings and an estimation of water demand by a water balance method (feed-forward control) (Fig. 2b). SL+WB used soil water tension data to correct the ET model prediction of water consumption. An irrigation event was scheduled based on Eq. 2 and stopped whenever a soil tension of $-30 \mathrm{kPa}$ (wet threshold) was detected.

\section{Canopy temperature signal and the TTT method (TTT)}

The TTT algorithm described in Evett et al. (1996) and examined in DeJonge et al. (2015) was the basis for the computer algorithm evaluated here. To determine the temperature threshold $\left(T_{\text {temp }},{ }^{\circ} \mathrm{C}\right)$, leaf samples were collected and sent in sealed refrigerated envelop to a lab in Lubbock, TX, where enzyme assays performed. The value of time threshold $\left(T_{\text {time }}, \mathrm{min}\right)$ was obtained from canopy temperature and meteorological measurements collected over wellirrigated apple trees in 2007 in the same orchard. The accumulated time $\left(t_{24}\right)$ during $24 h$ was calculated as the following:

$$
t_{24}=\sum_{\mathrm{m}=0}^{1440} m, \text { when } T_{m}>T_{\text {temp }}
$$

where $T_{m}$ is the canopy temperature $\left({ }^{\circ} \mathrm{C}\right)$ in minute $m$, and $T_{\text {temp }}$ is the temperature threshold. If $t_{24}>T_{\text {time }}$ then an irrigation signal was generated. The values of $t_{24}$ was reset to 0 every day at midnight. 
The net irrigation depth (I) was calculated as twice the average crop evapotranspiration $\left(\mathrm{I}=2 \times \mathrm{ET}_{\mathrm{c}}\right)$ in June and July (twice the peak crop water use), enough to wet the root zone at the highest ET rate in the region while avoiding deep percolation (O’Shaughnessy et al., 2010).

\section{Canopy temperature signal with the crop water stress index (CWSI)}

The CWSI algorithm relied on a theoretical CWSI and a dynamic threshold. The theoretical lower and upper boundaries of the CWSI were calculated using biophysical models thoroughly detailed by Osroosh et al. (2015b). The net irrigation depth (I) was calculated as three times the average crop evapotranspiration $\left(\mathrm{I}=3 \times \mathrm{ET}_{\mathrm{c}}\right)$ in June and July. This computer algorithm (called CWSI-DT) and its field evaluation results are also described in Osroosh et al. (2015b). Here, the results from the original experiment were compared with the rest of the approaches.

\section{Scientific-based method of measuring soil moisture using neutron probe (NP)}

The NP treatment was assumed to represent the best irrigation scheduling practice by an advanced farmer. In this approach, soil water content was measured with a field-calibrated neutron probe on a weekly basis. Using the soil moisture readings, soil water deficit (SWD) to field capacity was calculated and irrigation was scheduled. The soil water depletion under the NP treatment was never allowed to exceed a maximum allowed depletion (MAD of 50\%) recommended for apple trees (Allen et al., 1998). The net irrigation depth was calculated as $I=d \times\left[\theta_{F C}-\theta_{S}\right]$, where $d$ is the rooting depth $(d=0.6 \mathrm{~m})$, and $\theta_{s}$ is the average volumetric soil water content for $d$. Manual neutron probe readings (raw values) were entered into the GUI right after field measurements every Wednesday. Irrigation was automatically schdeuled based on the the entered reading for following day.

\section{Conventional irrigation scheduling in the region (CNTRL)}

In addition to the precision algorithms described, water delivery to a number of zones was managed using the conventional irrigation scheduling method of apple trees in the region. The CNTRL algorithm (Fig. 3) was designed to mimic the growers' approach of using the calendar (irrigation events on specific days of week) and weather conditions (low, high air temperature thresholds). In the CNTRL algorithm, any air temperature between the maximum $\left(T_{\text {Max }}\right)$ and minimum $\left(T_{\min }\right)$ thresholds would have resulted in applying $I_{b}=63 \mathrm{~mm}$ of water. If air temperature exceeded the maximum threshold $\left(T_{\operatorname{Max}}=32^{\circ} \mathrm{C}\right)$ the amount of irrigation water would be doubled $\left(I=2 \times I_{b}\right)$. If air 
temperature was below the minimum threshold $\left(T_{\min }=21^{\circ} \mathrm{C}\right)$, the trees would receive half the usual amount of water $\left(I=0.5 \times I_{b}\right)$.

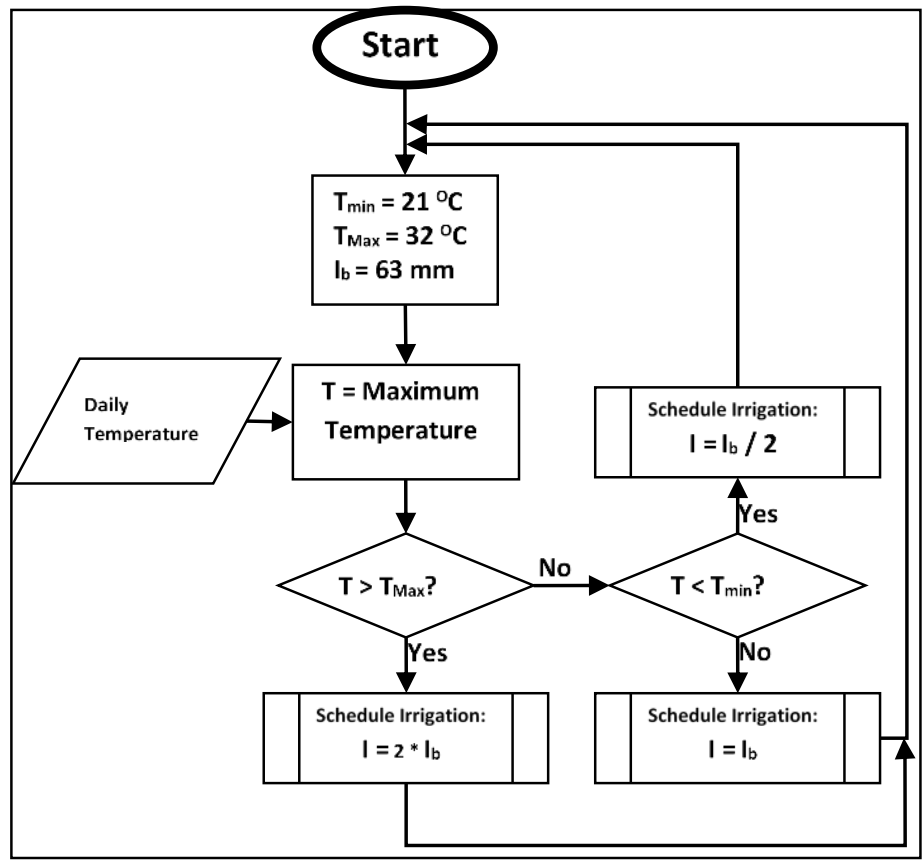

Figure 3. Flowchart of the traditional irrigation scheduling algorithm (CNTRL). $I$ is the amount of irrigation water applied, and $I_{b}$ is the base amount of water which was doubled or halved depending on minimum $\left(T_{\min }\right)$ and maximum $\left(T_{M a x}\right)$ air temperature thresholds.

\section{Graphical user interface}

A Windows-based GUI was developed in Microsoft VB.Net (V.2010, Microsoft Inc., Redmond, WA) to manage and control the irrigation system and wireless nodes. Embedded routines in CoraScript (V.1.1.9.8, Campbell Scientific, Logan, UT) were used to send command signals to the six slave nodes/dataloggers. LoggerNet (V.3.5, Campbell Scientific, Logan, UT) automatically downloaded data from the nodes every 15 min and populated a database on the laptop. The recorded data was then managed by the GUI. Fig. 4 shows a task flowchart of systems' software and firmware components and their relationship. Instead of wireless communication between the field and office computers, Teamviewer (V.8, TeamViewer Pty Ltd, Adelaide, Australia) was used to remotely access the GUI in the field.

The GUI has a tabular design and comprises several tabs including: 1) a "Blocks" tab for displaying raw realtime data from the in-field sensors and valves on/off status, 2) a tab for showing real-time weather data ("Roza"), and 
3) a tab for monitoring the commands sent out and program codes in action ("Console"). Fig. 5 shows a screenshot of the "Blocks" tab. The rest of the tabs were dedicated to system settings, crop and soil properties, sensor calibration parameters, and entering manual field measurements into the GUI. The GUI was capable of running in three main functioning modes: simulation, automatic irrigation and manual irrigation. The simulation and manual modes were used for the purpose of testing the system's hardware and software. The simulation mode was added mainly to test the internal functions without having to operate the hardware. The manual mode, on the other hand, allowed for testing and tuning the hardware more easily.

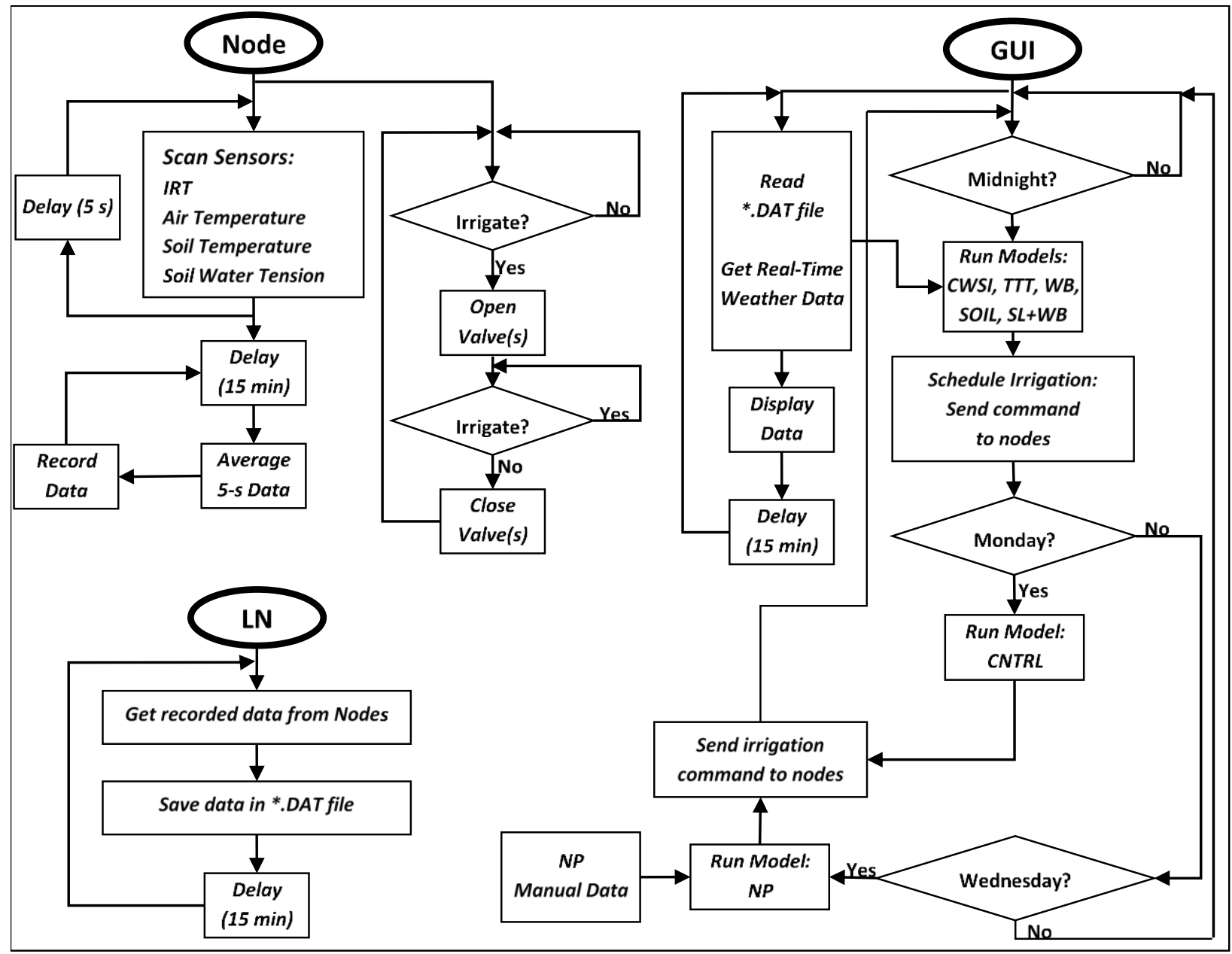

Figure 4. Flowchart displaying the routines performed by the software (LN and GUI) and firmware (Node) components of the control and monitoring system. The node firmware was responsible for scanning the sensors and sending the collected data to the base. LoggerNet (LN) regularly retrieved data from the nodes and recorded them in a file. The GUI used this data to run the irrigation algorithms, and make irrigation control decision. 
The GUI collected data from the sensor nodes, downloaded weather data from the nearby weather station, and provided a real-time display of the measurements in individual zones regardless of the node collecting them. The remaining irrigation time corresponding to each sensor/plot was displayed next to the sensor's name. The GUI ran the irrigation scheduling algorithms (WB, SOIL, SL+WB, TTT, CWSI, NP and CTNRL) every day at midnight, and automatically made decisions for scheduling irrigation events for twenty-one individual zones within the orchard. It sent control signals to the individual data-loggers which opened or closed latching solenoid valves to turn the water on and off to each block of trees. The software also allowed for manual control of individual zones.

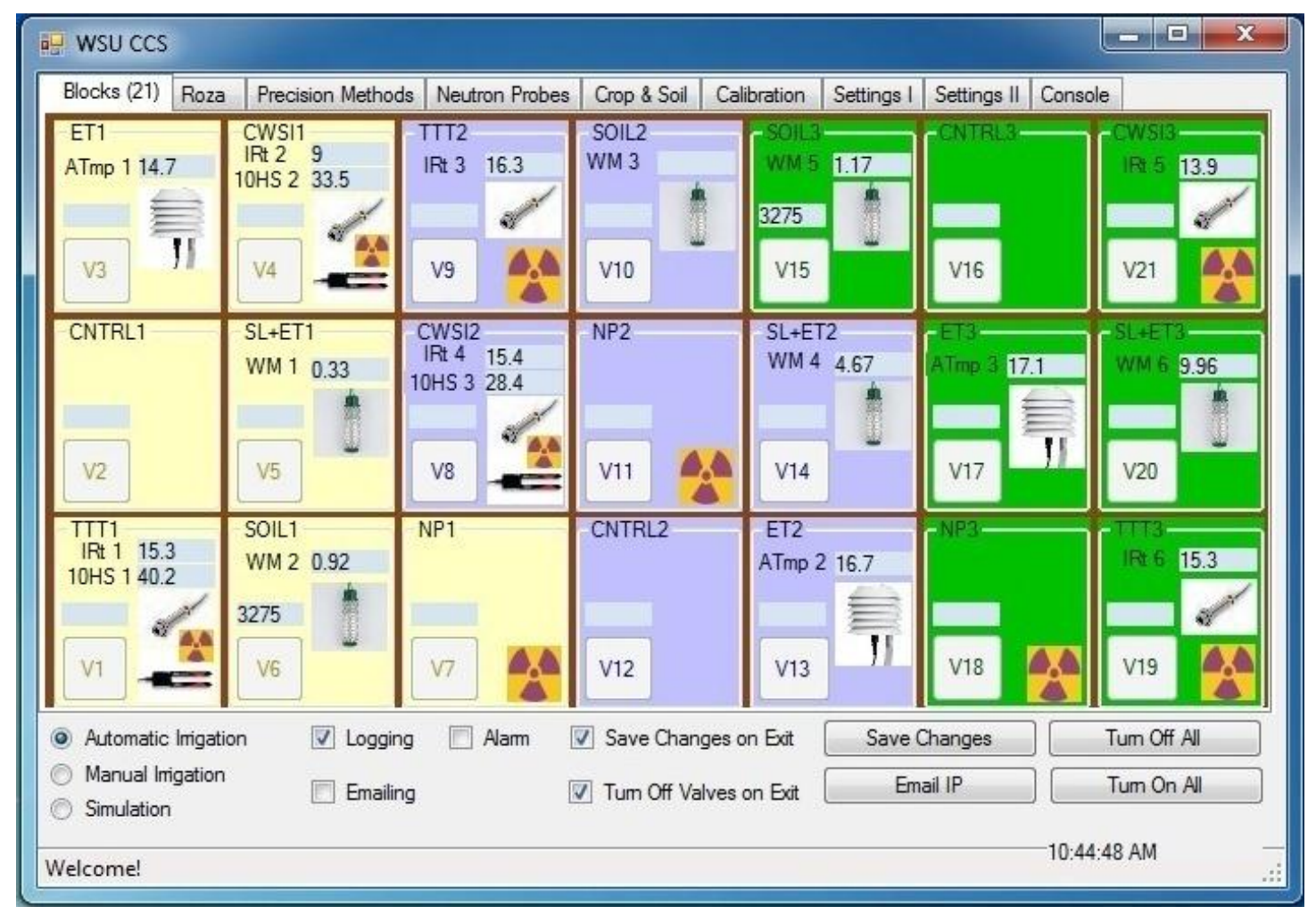

Figure 5. Screenshot of the "Blocks" tab of the graphical user interface. In this tab, sensor readings taken by the in-field sensors and remaining irrigation time are displayed in real-time. The values were updated every $15 \mathrm{~min}$.

The data recorded in the database by LoggerNet were automatically pulled by the GUI and used to execute the algorithms in parallel everyday at midnight. This led to generating irrigation schedules for 10:30AM of following day. The exceptions were the CNTRL and NP algorithms which were, respectively, run only on Mondays and Wednesdays as depicted in the flowchart in Fig. 4. The decision support process for the SOIL and SL+WB algorithms was slightly 
different as a continuous monitoring of feedback from the in-field Watermark ${ }^{\mathrm{TM}}$ sensors (every 15 min) was required to determine the end of irrigation event.

LoggerNet was responsible for handling wireless communication errors and retries. The GUI monitored dataloggers battery voltage levels, handled coding errors and sent alert and digestion emails to the user. The system routinely logged irrigation events and reported the start/stop time of irrigations via email to the user. Due to possible exposure of in-field sensors to malfunction and disturbances, sensor-specific routines automatically analyzed the data for any signs of failure or anomalies such as abnormally high or low values beyond the expected range for a variable and negative/erroneous sensor readings. Noise or temporary abnormal changes in values were handled by the software and those of serious nature were reported back to the user via email. Besides the software error handling, the status of the wireless network was checked by the user regularly.

\section{Experimental design and statistical analysis}

The seven irrigation treatments were evaluated in a randomized complete block design with three replications/blocks, each plot consisting of three rows of 6 trees (21 management zones). The trees at the center of the plots were used for measurement purpose. The plots were also observed for tree health and difference in the size and quality of apple fruits. The statistical analysis methods included the standard error of the mean (SE of Mean), and analysis of variance (ANOVA) using SigmaPlot (V.11.0, Systat Software Inc., San Jose, CA) to test for difference

among the treatments in terms of applied irrigation water $\left(\mathrm{mm} \mathrm{season}^{-1}\right)$. To conduct multiple comparisons of the means, the Bonferroni t-test was employed (at $p=0.05$ ).

\section{Results and discussion}

During the 2007 growing season when the time threshold for TTT was determined, maximum daily evapotranspiration $\left(E T_{\text {Max }}\right)$, total applied irrigation water $\left(I_{t}\right)$, total rainfall (May-September), and total irrigation days $\left(d_{t}\right)$ were calculated to be $9.7 \mathrm{~mm} \mathrm{~d}^{-1}, 1077 \mathrm{~mm} \mathrm{season}^{-1}, 32 \mathrm{~mm}$ and $110 \mathrm{~d}$, respectively. The theoretical temperature threshold returned by the lab was $10^{\circ} \mathrm{C}$ and the corresponding time threshold to this value was $1035 \mathrm{~min}$. Considering the low value determined by the lab, a range of time threshold $\left(T_{\text {time }}\right)$ and temperature threshold $\left(T_{\text {temp }}\right)$ values were plotted against each other. The temperature threshold was then chosen to be $22.2^{\circ} \mathrm{C}$, and an irrigation 
event $(I=2 \times 5.5=11 \mathrm{~mm})$ was scheduled following a day when canopy temperature exceeded $T_{\text {temp }}=22.2^{\circ} \mathrm{C}$ for more than $225 \mathrm{~min}$.

The rainfall totaled $91 \mathrm{~mm}$ from May through September of 2013 most of which $(77 \mathrm{~mm})$ occurred in May and July. The 2013 growing season was relatively warmer compared to the 2007 growing period with greater daily mean temperatures, $E T_{r}$ values (Table 1) and $E T_{\text {Max }}$ of $14.0 \mathrm{~mm} \mathrm{~d}^{-1}$. Considerable amount of rainfall received during May and June, a number of manual irrigation events, and presence of a perched water table in the study site led to the availability of enough moisture in the root zone until June $\left(\theta_{s}>\theta_{M A D}=\right.$ soil moisture at MAD). As a result, the automatic irrigation system did not become operational until the soil water profile reached a defined irrigation trigger point. The wireless control system was configured and tested during March, April and May, and automatically managed the water delivery to the plots during the rest of the season. The number of automatic irrigation days was less than $100 d$ for most of the treatments.

Table 1. Climatic conditions for the 2007 and 2013 growing seasons.

\begin{tabular}{lcccc}
\hline Month & Mean temperature $\left({ }^{\circ} \mathrm{C}\right)$ & Mean RH $(\%)$ & Total rainfall $(\mathbf{m m})$ & Average daily $_{\mathbf{E T}}\left(\mathbf{m m d}^{\mathbf{- 1}}\right)$ \\
\hline Growing Season & $\mathbf{2 0 0 7}$ & & & \\
\hline May & 15.0 & 55.9 & 6.1 & 4.1 \\
\hline June & 19.1 & 64.8 & 14.7 & 2.8 \\
\hline July & 23.5 & 61.1 & 2.5 & 7.6 \\
\hline Aug & 21.0 & 60.7 & 3.0 & 7.5 \\
\hline Sept & 16.6 & 59.6 & 5.6 & 5.2 \\
\hline Growing Season & $\mathbf{2 0 1 3}$ & & & \\
\hline May & 15.5 & 60.0 & 33.8 & 5.9 \\
June & 23.9 & 68.5 & 42.9 & 6.5 \\
\hline July & 27.8 & 46.3 & 0.0 & 8.9 \\
\hline Aug & 27.3 & 64.7 & 5.3 & 6.2 \\
\hline Sept & 21.5 & 69.0 & 9.1 & 4.8 \\
\hline
\end{tabular}

\section{Applied irrigation water}

The ANOVA test revealed that the difference in the mean values among the seven irrigation treatments was significant $(p<0.001)$. A comparison of the treatments in terms of total irrigation water applied can be found in Table 2. The applied water for CNTRL was significantly higher than all other treatments with a value of $1359 \mathrm{~mm}$. This was over three times $(340 \%)$ the amount of water applied by NP (401 $\mathrm{mm})$. On the other hand, SOIL resulted in the lowest mean applied water $(214 \mathrm{~mm})$ which was $53 \%$ of the amount delivered by NP. WB, CWSI and TTT applied 
469, 408 and $436 \mathrm{~mm}$ of water, respectively (no significant difference: $p=1$ ), which accounted for slightly more than $100 \%$ of water applied by NP and resulted in about $70 \%$ water saving over the irrigation period. The WB algorithm applied significantly greater amount of water than SOIL $(p<0.001)$ and SL+WB $(p=0.004 ; 273 \mathrm{~mm})$. There was no significant difference between CWSI and SL+WB $(p=0.072)$. SOIL applied significantly less amount of water than the rest of the treatments, while there was no significant difference between NP and SL+WB $(p=0.1)$.

Table 2. Comparison of total irrigation water $\left(\mathrm{I}_{t}, \mathrm{~mm}\right)$ applied under seven irrigation treatments.

\begin{tabular}{|c|c|c|c|c|c|c|c|}
\hline Treatment $^{*}$ & CNTRL & WB & TTT & CWSI & $\mathbf{N P}$ & SL+WB & SOIL \\
\hline Total Applied Water $(\mathrm{mm})^{* *}$ & $1359 \mathrm{~A}$ & 469B & $436 \mathrm{~B}$ & 408BC & 401BC & $273 \mathrm{CD}$ & $214 \mathrm{D}$ \\
\hline SE of Mean $(\mathrm{mm})$ & 0 & 11 & 3 & 56 & 25 & 43 & 32 \\
\hline$I_{t} / I_{N P}(\%)^{* * * *}$ & 339 & 117 & 109 & 102 & Reference & 68 & 53 \\
\hline$I_{t} / I_{C N T R L}(\%)^{* * * *}$ & Control & 35 & 32 & 30 & 30 & 20 & 16 \\
\hline
\end{tabular}

${ }^{*}$ The treatments were 1) water budget (WB), 2) soil water tension sensor (SOIL), 3) a combination of WB and SOIL algorithms (SL+WB),

4) irrigation scheduling using neutron probe as reference (NP), 5) the time and temperature threshold (TTT), and 6) crop water stress index (CWSI), and 7) conventional irrigation scheduling as control (CNTRL).

${ }^{* * *}$ Each value represents the average of three measurements per treatment. Means indicated by the same letter are not significantly different at $\boldsymbol{p}=0.05$

${ }^{* * * *} I_{N P}$ : total applied water for NP, $I_{C N T R L}$ : total applied water for CNTRL

The Watermark ${ }^{\mathrm{TM}}$ sensor readings showed no sign of water stress in the plots of SOIL and SL+WB as the soil water potential fluctuations were within the range of 0 to $-80 \mathrm{kPa}$ (Fig. 6a). However, field inspections disclosed that the trees under the SL+WB algorithm may have been severely water-stressed as leaf drop and loss of turgidity, trees reduced overall growth, and abnormally small fruits in these plots were evident. Having under-irrigated the trees, SOIL and SL+WB exhibited an insufficient response to water stress. The under-irrigation of the plots under SOIL can be explained by the fact that the soil sensors monitored only a limited volume of the soil profile and might have not

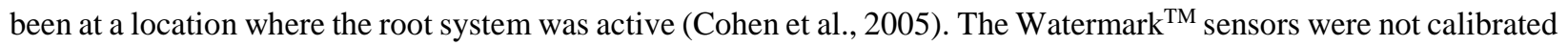
and single predefined wet and dry thresholds were applied to all of them. In addition, it was difficult to make a representative tension measurement due to the heterogeneity of soil water distribution under the drip irrigation system.

Using a feed-forward ET-based scheduling method in combination with a soil feedback (SL+WB) did not improve irrigation scheduling as signals to stop irrigation were perhaps issued too soon. The general algorithm of 
Casadesús et al. (2012) suggests that the use of the water balance model allows for a quick response to weather changes by predicting its effects, while at the same time the feedback mechanism can adapt the amount of water to the requirements of individual orchards by compensating for prediction errors. However, the accuracy of feedback is very important. Currently, available soil water content sensors including Watermark ${ }^{\mathrm{TM}}$ sensors cannot provide the required precision as achievable with the neutron probe.

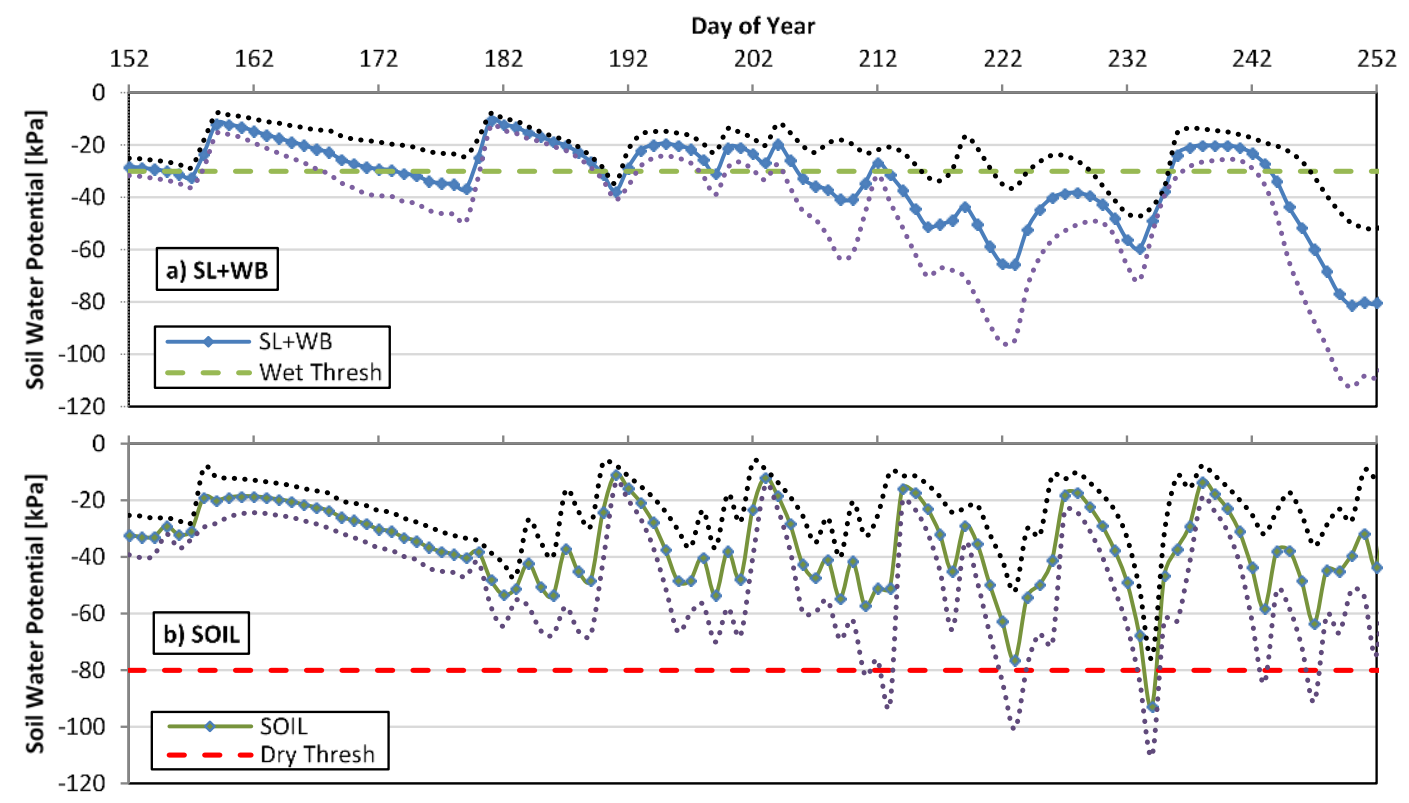

Figure 6. Graphical display of in-field Watermark ${ }^{\mathrm{TM}}$ sensors data collected using the wireless sensor network: mean of three plots under the SL+WB (a), and SOIL (b) treatments. The dotted lines show the standard error of the mean. The dashed lines show the wet (Wet Thresh) and dry (Dry Thresh) thresholds.

The soil water content of the plots under the CWSI and TTT treatments was measured weekly as for the NP plots. As depicted in Fig. 7a, mean soil water deficit (SWD) in the treatment plots of CWSI, TTT and NP in the top $0.6 \mathrm{~m}$ was within the well-watered range (<MAD of 50\%). Mean SWD in the TTT plots was significantly lower than NP $(p<0.001)$ which was in agreement with applying slightly more irrigation water under TTT (not significant). Seasonal courses of midday $\psi_{\text {stem }}$ for the trees under CWSI and TTT are depicted in Fig. 7b. It can be seen that the trees under TTT maintained a relatively similar values of $\Psi_{\text {stem }}$ to the trees under CWSI over the period. The measured values of $\Psi_{\text {stem }}$ agreed well with non-stressed values reported for woody plants including apple trees (De Swaef et al., 2009; Naor and Cohen, 2003). As discussed in Osroosh et al. (2015b), the CWSI algorithm demonstrated a good 
response to the water status of the apple trees. The results here support the use of the TTT thermal-based approach to maintain well-watered apple trees under drip irrigation system in the semi-arid climate of central Washington.
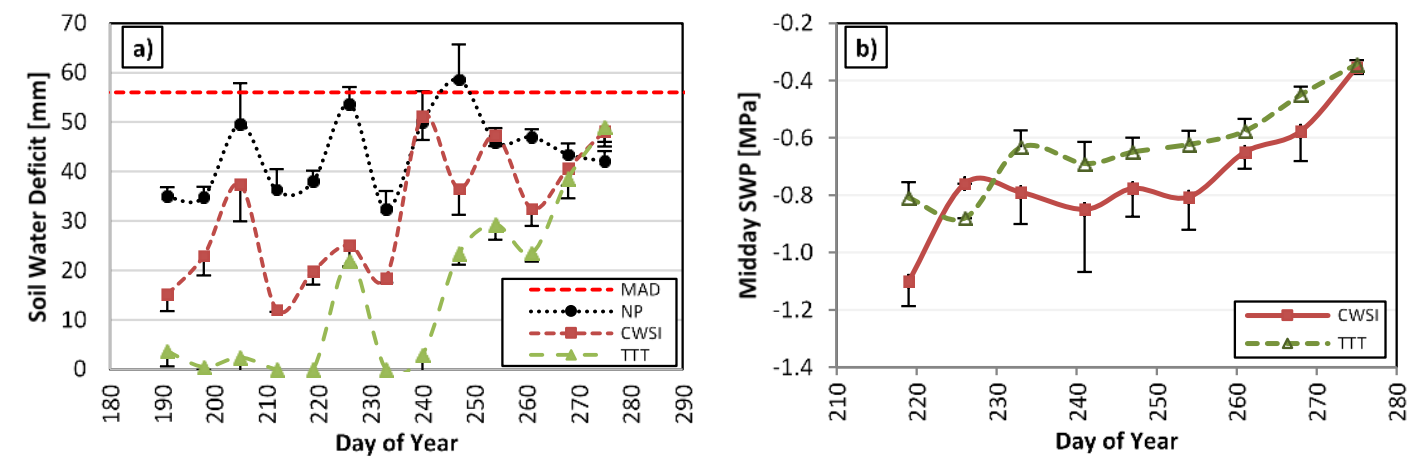

Figure 7. Mean soil water deficit in the plots under the NP, CWSI and TTT treatments in the top $0.6 \mathrm{~m}$ (a). The straight dashed line specifies a MAD of $50 \%$ (equivalent to $56 \mathrm{~mm}$ for the meaured depth). Seasonal courses of midday $\psi_{\text {stem }}$ in the CWSI and TTT treatments (b). The error bars show the standard error of the mean.

The cumulative applied water for individual plots under TTT, WB and CWSI is illustrated in Fig. 8a-b for the growing period of 2013. Plots within the TTT and WB treatments had similar amounts of irrigation water delivered to them during the season, whereas the plots under CWSI showed some degree of variability. WB did not receive any feedback from the trees, thus microclimatic variability within the orchard was the only source of discrepancy among the plots and consequently the irrigation depths. The WB algorithm can lead to over- or under-irrigation if the estimates of crop water use are incorrect, the soil water content at the beginning of the season is unknown, or the application efficiency of irrigation system is lower than expected (Fereres et al., 2012). Apple trees have shown to close their stomata in response to a reduction in fruit loads (Palmer et al. 1997; Lakso 2003; Girona et al. 2011). This reduction in evapotranspiration can challenge the WB approach as a lack of plant feedback may lead to significant errors in the estimations of water needs. The CWSI algorithm required meteorological data in addition to canopy temperature as input meaning it had to respond to atmospheric demand and signs of plant stress. This is while TTT only responded to increased canopy temperature which could be a result of increased air relative humidity not stomatal closure driven by water stress (Wanjura and Upchurch, 1997; Jones, 2004). This is reflected in TTT having a wetter soil profile as depicted in Fig. 7a. The CWSI algorithm, on the other hand, had a mechanism for withholding irrigation on humid days. It is known that CWSI values measured on cool and humid days are not reliable generating false stress signals 
and consequently resulting in over irrigation (Osroosh et al., 2015b). The CWSI algorithm interprets CWSI value in relation to the air relative humidity level and no irrigation decision is made on a humid day.
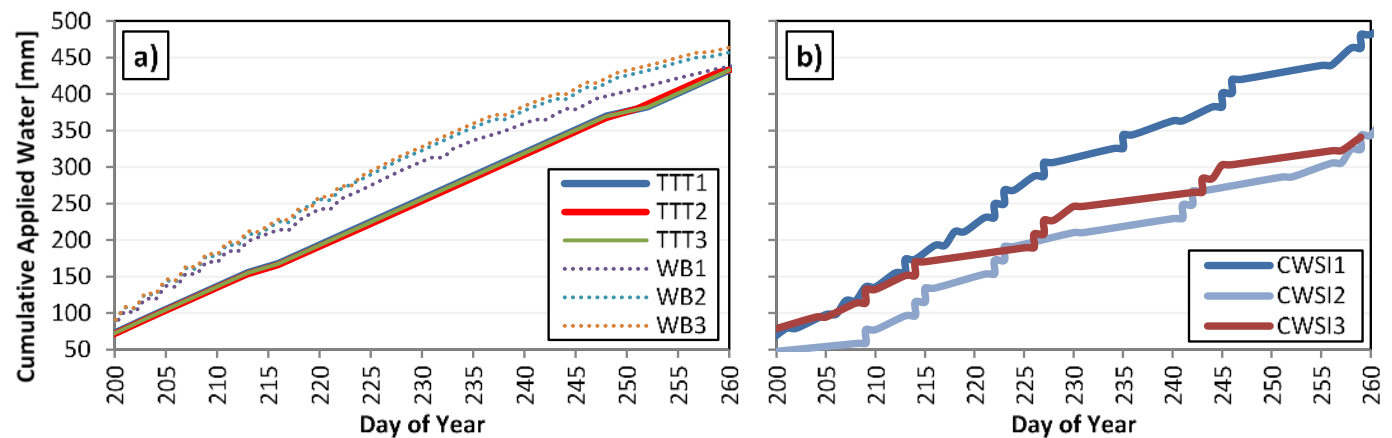

Figure 8. Cumulative applied irrigation water for the treatment plots of TTT (1-3) and WB (1-3) (a), and CWSI (1-3) (b).

\section{Trees growth and fruit yield}

Due to the fact that the trees were in an alternate bearing year, no quantitative information on the fruit yield was collected. However, our observations revealed that apple size in the SOIL and SL+WB treatments was noticeably smaller than CNTRL and never ripened (same number of fruits on trees). Larger shoot growth in the CNTRL treatment was observed compared with a much lower shoot and foliage growth in the SOIL and SL+WB treatments leading to shorter trees. The distance between rows in the CNTRL was covered with grass or algae and was always wet. This was not the case in other treatments.

\section{Labor requirement and cost}

In the discussed control and monitoring system, the algorithms were executed using commercially available hardware and off-the shelf components. The major hardware cost included Campbell Scientific dataloggers and IRT sensors. We used an old model notebook as the central processing hardware which was worth roughly $\$ 100$ (U.S. dollars). The base cost of a sensing and actuating unit with the current hardware (datalogger, radio, battery, solar panel, actuator, 4 latching solenoids) is approximately $\$ 2,500$ in 2016. Considering the available commercial options, an IRT sensor adds an additional amount of \$450-655 per measurement point. A soil/air temperature probe (without the shield) and a Watermark ${ }^{\mathrm{TM}}$ sensor can be purchased for $\$ 100$ and $\$ 35-120$, respectively. In the calculation of the 
cost, we replaced the CR10X with the CR1000 (Campbell Scientific, Logan, UT), and the RF401 with the RF401A (Campbell Scientific, Logan, UT) as they are no longer manufactured by the company.

Table 3. Approximate price for an automatic ag-weather station, base station, and components of a typical sensing and actuating station in 2016.

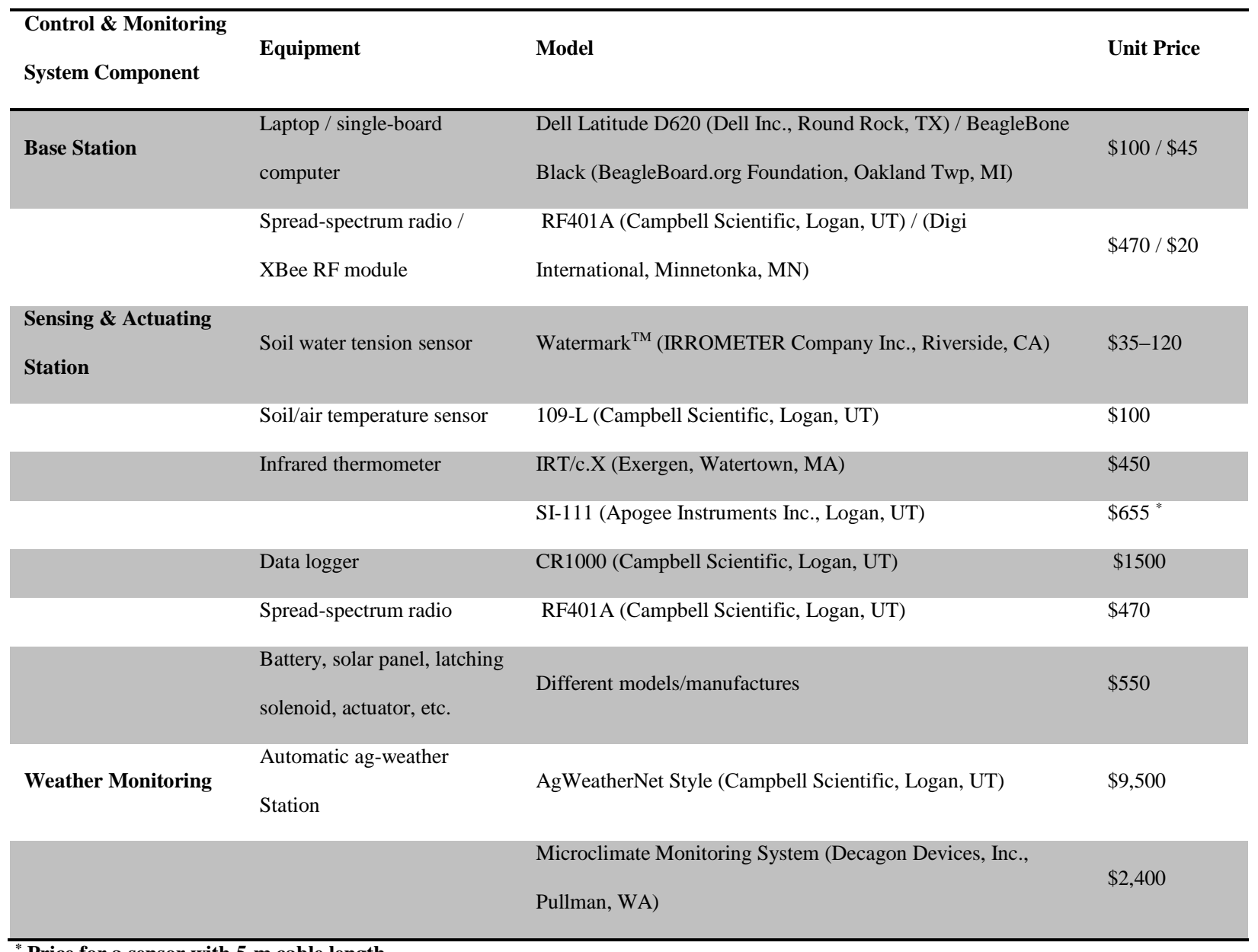

Price for a sensor with 5-m cable length.

We obtained real-time meteorological data from a nearby weather station which was part of the WSU AgWeatherNet. The cost of such a station in case a farmer decides to invest in one is $\$ 9,500$ (sensors, hardware, installation, first year maintenance) (AgWeatherNet, 2013). Major costs for the control and monitoring system and alternative options for some components are summarized in Table 3 for comparison. A summary of the irrigation scheduling algorithms evaluated in the present study including the in-field sensor requirements, total upfront cost, advantages and shortcomings of the system are also summarized in table 4 . 
Table 4. Summary of the seven computerized irrigation scheduling algorithms evaluated in the present study.

\begin{tabular}{|c|c|c|c|c|c|}
\hline Algorithm & Description & $\begin{array}{l}\text { In-field } \\
\text { Measurements }\end{array}$ & $\begin{array}{l}\text { Upfront Cost } \\
\text { (per unit sensor) }\end{array}$ & Weaknesses & Strengths \\
\hline ET & $\begin{array}{l}\text { Weather-based, soil water balance } \\
\text { using a temperature-only-based ET } \\
\text { equation, feed-forward control }\end{array}$ & Air temperature & $\$ 100$ & $\begin{array}{l}\text { No plant or soil feedback, } \\
\text { model prediction errors can } \\
\text { lead to over/under irrigation }\end{array}$ & $\begin{array}{l}\text { Automatic, no need for field } \\
\text { calibration, low upfront cost }\end{array}$ \\
\hline TTT & $\begin{array}{l}\text { Plant-based, the Time and } \\
\text { Temperature Threshold method, } \\
\text { feedback control }\end{array}$ & $\begin{array}{l}\text { Air temperature, } \\
\text { canopy temperature } \\
\text { using IRT }\end{array}$ & $\$ 550-755$ & $\begin{array}{l}\text { Proper installation of IRT is } \\
\text { difficult, IRT maintenance } \\
\text { (mainly cleaning), false } \\
\text { stress signal on humid days }\end{array}$ & $\begin{array}{l}\text { Automatic, no need for site- } \\
\text { specific calibration, crop- } \\
\text { specific precision }\end{array}$ \\
\hline CWSI & $\begin{array}{l}\text { Plant- \& weather-based, Crop } \\
\text { Water Stress Index with dynamic } \\
\text { threshold (CWSI-DT), adaptive } \\
\text { feedback control }\end{array}$ & $\begin{array}{l}\text { Meteorological, } \\
\text { canopy temperature } \\
\text { using IRT }\end{array}$ & $\$ 2,850-11,550 *$ & $\begin{array}{l}\text { Proper installation of IRT is } \\
\text { difficult, IRT maintenance } \\
\text { (mainly cleaning), upfront } \\
\text { cost can be high }\end{array}$ & $\begin{array}{l}\text { Automatic, no need for site- } \\
\text { specific calibration, site- } \\
\text { and crop-specific precision }\end{array}$ \\
\hline SOIL & $\begin{array}{l}\text { Soil-based, soil moisture } \\
\text { monitoring and wet/dry thresholds, } \\
\text { feedback control }\end{array}$ & $\begin{array}{l}\text { Soil tension using } \\
\text { Watermark }^{\mathrm{TM}} \text {, soil } \\
\text { temperature }\end{array}$ & $\$ 135-220$ & $\begin{array}{l}\text { Site-specific calibration } \\
\text { required, under-irrigation, } \\
\text { late response to water stress }\end{array}$ & Automatic, low upfront cost \\
\hline SL+ET & $\begin{array}{l}\text { Soil- \& weather-based, combination } \\
\text { of ET and SOIL algorithms } \\
\text { (feedback + feed-forward) }\end{array}$ & $\begin{array}{l}\text { Soil tension using } \\
\text { Watermark }^{\mathrm{TM}} \text {, air } \\
\text { temperature, soil } \\
\text { temperature }\end{array}$ & $\$ 235-320$ & $\begin{array}{l}\text { Site-specific calibration } \\
\text { required, under-irrigation, } \\
\text { late response to water stress }\end{array}$ & Automatic, low upfront cost \\
\hline NP & $\begin{array}{l}\text { Soil-based, refills soil water deficit } \\
\text { to field capacity, scientific method } \\
\text { (reference) }\end{array}$ & $\begin{array}{l}\text { Soil water content } \\
\text { using neutron probe }\end{array}$ & $\$ 4000-6000$ & $\begin{array}{l}\text { Manual, labor-intensive, } \\
\text { relatively high upfront cost }\end{array}$ & No under- or over-irrigation \\
\hline CNTRL & $\begin{array}{l}\text { Mimics conventional irrigation by } \\
\text { local growers, no sensor feedback }\end{array}$ & None & None & $\begin{array}{l}\text { Manual }{ }^{* *}, \text { labor-intensive, } \\
\text { over-irrigation, excessive } \\
\text { shoot growth }\end{array}$ & No upfront cost \\
\hline
\end{tabular}

"The cost is reduced to $\$ 450-655$ (IRT cost) if a nearby weather station is available.

*** This technique is manual in nature, however we developed and implemented an automatic algorithm based on the original conventional irrigation practice.

Although the GUI was designed to manage a specific orchard, it has the potential to be retrofitted to other irrigation systems or fields. Especially for research purposes, the laptop/PC and dataloggers can be replaced with Linux-based single-board computers such as the BeagleBone Black (BeagleBoard.org Foundation, Oakland Twp, MI), and the Spread-spectrum radio with the XBee RF module (Digi International, Minnetonka, MN) to significantly reduce 
the cost. A network of inexpensive air temperature sensors can provide enough microclimatic data for estimation of ET. The WB algorithm requires only an air temperature sensor with no need for calibration which keeps the labor and capital investments very low. CWSI needs a network of infrared thermometers and meteorological sensors with no need for site-specific calibration. From both research and practice perspectives, the capital cost and labor requirements of both CWSI and TTT are relatively low; however, regular maintenance (mainly cleaning) of IRTs is necessary to keep the network up and running.

Despite the low sensor cost and ease of implementation, SOIL and SL+WB did not show to be reliable in terms of delivering enough water to stressed trees or detecting stress on-time. To achieve higher accuracies, using a larger number of Watermark ${ }^{\mathrm{TM}}$ sensors to account for sources of variability, calibration of individual sensors, or a combined use of soil water potential and soil water content sensors appears to be necessary. The maintenance was a major issue with the soil sensors wiring. There were several cases of wire damage accidents due to animal rodent activity in the field. Wireless IRTs (O’Shaughnessy et al., 2013) and less commonly wireless soil sensors are alternatives to wired sensors which will also lead to reduced installation and maintenance cost. These results support the suitability of simple irrigation scheduling techniques like WB for the automatic irrigation of apple orchard. Approaches like CWSI, TTT and WB are slightly more expensive, however they provide a higher degree of reliability compared to SOIL or SL+WB strategies.

\section{Conclusions}

In this study, we developed and initially evaluated seven irrigation scheduling algorithms including two wellknown plant/thermal-based strategies of the Time and Temperature Threshold (TTT) and Crop Water Stress Index (CWSI). Irrigation water delivery was automatically scheduled to twenty-one management zones in an apple orchard using a wireless control and monitoring system. Precision irrigation algorithms were compared with the scientificbased method of irrigation scheduling using neutron probe and the conventional approach in the region in terms of ability to improve the current practice and simplicity of implementation from grower's perspective. Our preliminary results supported the use of weather- and plant-based algorithms, decision support and monitoring software, and wireless sensor network for automatic irrigation management of drip-irrigated apple trees. 
The weather- and plant-based algorithms evaluated here were able to deliver enough irrigation water to the apple trees and avoid water stress. The soil-based approaches, on the other hand, failed to deliver enough water to the trees which resulted in severe water stress and impaired growth. The weather- and plant-based methods exhibited a promising performance at the level of the scientific irrigation scheduling method in terms of applying precise of amount of water when it was needed and had the great advantage of being fully automatic. While the weather-based control algorithm showed a similar performance to the plant-based methods under the conditions of the experimental site, we believe a control algorithm with plant feedback is a superior choice when it comes to site- and crop-specific precision.

This was an initial step towards implementing automatic irrigation on drip-irrigated apple trees. The presented irrigation scheduling approaches have the potential to improve water use efficiency, increased production, reduced production costs, reduced pumping energy requirements, and improved quality. Here, we mainly examined the various hardware and software aspects of a supervisory control and data acquisition (SCADA) system and the suitability of the irrigation scheduling algorithms for maintaining well-watered trees. Future studies will reveal more on their benefits for decreasing losses of water and nutrients to deep percolation and their effect on yield and fruit quality.

\section{Acknowledgments}

This research was funded by the US Department of Agriculture Specialty Crop Research Initiative (USDA SCRI) grant. The authors also acknowledge the assistance and support of the Center for Precision and Automated Agricultural Systems (CPAAS) and AgWeatherNet (AWN) program at Washington State University.

\section{References}

Abreu, V.M., Pereira, L.S., 2002. Sprinkler irrigation systems design using ISAMim. ASABE, Paper No. 022254, St. Joseph, MI.

Agam, N., Cohen, Y., Berni, J.A.J., Alchanatis, V., Kool, D., Dag, A., Yermiyahu, U., Ben-Gal, A., 2013. An insight to the performance of crop water stress index for olive trees. Agr. Water Manage., 118: 79-86. 
AgWeatherNet, 2013. AgWeatherNet New Station Policy. Washington State University. http://weather.wsu.edu/AgWeatherNet/StationSupport.pdf.

Al-Kaisi, M.M., Berrada, A., Stack, M., 1997. Evaluation of irrigation scheduling program and spring wheat yield response in southwestern Colorado. Agr. Water Manage., 34: 137-148.

Allen, R.G., Pereira, L.S., Raes, D., Smith, M., 1998. Crop evapotranspiration: guidelines for computing crop water requirements. Irrigation and Drainage Paper No. 56. FAO, Rome, Italy, 300 pp.

Allen, R.G., Walter, I.A., Elliott, R.L., Howell, T.A., Itenfisu, D., Jensen, M.E., Snyder, R.L., (Eds.), 2005. ASCE standardized reference evapotranspiration equation (ASCE-EWRI), Reston, VA, 69.

Atkinson, D., 1980. The distribution and effectiveness of the roots of tree crops. Horticultural Reviews, 2: 424-490.

Berni, J.A.J., Zarco-Tejada, P.J., Sepulcre-Cantó, G., Fereres, E., Villalobos, F., 2009. Mapping canopy conductance and CWSI in olive orchards using high resolution thermal remote sensing imagery. Remote Sens. Environ., 113: $2380-2388$.

Black, B., Hill, R., Cardon, G., 2008. Orchard irrigation: Apple. USU Extension Publication: Horticulture/Fruit/200801pr. https://extension.usu.edu/files/publications/publication/Horticulture_Fruit_2008-01pr.pdf

Cardenas-Lailhacar, B., Dukes, M.D., Miller, G.L., 2008. Sensor-based automation of irrigation on bermudagrass, during wet weather conditions. J. Irrig. Drain. Eng., 134: 120-128.

Cardenas-Lailhacar, B., Dukes, M.D., Miller, G.L., 2010. Sensor-based automation of irrigation on bermudagrass, during dry weather conditions. J. Irrig. Drain. Eng., 136: 184-193.

Casadesús, J., Mata, M., Marsal, J., Girona, J., 2012. A general algorithm for automated scheduling of drip irrigation in tree crops. Comput. Electron. Agr., 83: 11-20.

Coates, R.W., Delwiche, M.J., Broad, A., Holler, M., 2013. Wireless sensor network with irrigation valve control. Comput. Electron. Agr., 96: 13-22.

Cohen, Y., V. Alchanatis, M. Meron, Y. Saranga, and J. Tsipris. 2005. Estimation of leaf water potential by thermal imagery and spatial analysis. J. Exp. Bot. 56(417):1843-1852.

Davis, S.L., Dukes, M.D., Miller, G.L., 2009. Landscape Irrigation by Evapotranspiration-Based Irrigation Controllers under Dry Conditions in Southwest Florida. Agr. Water Manage., 96: 1828-1836.

Davis, S.L., Dukes, M.D., 2010. Irrigation Scheduling Performance by Evapotranspiration-based Controllers. Agr. Water Manage., 98: 19-28. 
DeJonge, K.C., Taghvaeian, S., Trout, T.J., Comas, L.H., 2015. Comparison of canopy temperature-based water stress indices for maize. Agr. Water Manage., 156: 51-62.

De Swaef, T., Steppe, K., Lemeur, R., 2009. Determining reference values for stem water potential and maximum daily trunk shrinkage in young apple trees based on plant responses to water deficit. Agr. Water. Manage., 96:541-550.

Dukes, M. D., M. L. Shedd, and S.L. Davis. 2009. Smart Irrigation Controllers: Operation of EvapotranspirationBased Controllers. AE446. Gainesville: University of Florida Institute of Food and Agricultural Sciences. http://edis.ifas. ufl.edu/ae446.

Enciso, J., Wiedenfeld, B., Jifon, J., Nelson, S., 2009. Onion yield and quality response to two irrigation scheduling strategies. Sci. Hortic-Amsterdam, 120: 301-305.

Evett, S.R., Schwartz, R.C., Tolk, J.A., Howell, T.A., 2009. Soil profile water content determination: spatio-temporal variability of electromagnetic and neutron probe sensors in access tubes. Vadose Zone J., 8 (4): 1-16.

Farahani, H.J., Howell, T.A., Shuttleworth, W.J., Bausch, W.C., 2007. Evapotranspiration: progress in measurement and modeling in agriculture. Trans. ASABE, 50: 1627-1638.

Girona, J., Del Campo, J., Mata, M., Lopez, G., Marsal, J., 2011. A comparative study of apple and pear tree water consumption measured with two weighing lysimeters. Irrigation Sci., 29: 55-63.

Fereres, E., Goldhamer, D., Sadras, V.O., 2012. In Crop yield response to water of fruit trees and vines: guidelines. Steduto, P., Hsiao, T.C., Fereres, E. and Raes, D. (eds.). Ch. 4, pp 246-295.

Hargreaves, G.H., Samani, Z.A., 1985. Reference crop evapotranspiration from temperature. Appl. Eng. Agric., 1(2): 96-99.

Hess, T., 1996. A microcomputer scheduling program for supplementary irrigation. Comput. Electron. Agr., 15: 233243.

Jackson, R.D., Idso, S.B., R.J.E., Reginato, Pinter, P.J., 1981. Canopy temperature as a crop water stress indicator. Water Resour. Res., 17: 1133-1138.

Jackson, R.D., Kustas, W.P.E., Choudhury, B.J., 1988. A reexamination of the crop water stress index. Irrig. Sci., 9: 309-317.

Jones, H., 2004. Irrigation scheduling: advantages and pitfalls of plant-based methods. J. Exp. Bot. 55, 2427-2436. 
Karimi, T., Peters, R.T., Stockle, C.O., 2013. Revising Crop Coefficient for Washington State. ASABE Paper No. 131612436, Kansas City, Missouri.

Kim, Y., Evans, R.G., 2009. Software design for wireless sensor-based site-specific irrigation. Comput. Electron. Agr., 66: 159-165.

Kisekka, I., Migliaccio, K.W., Dukes, M.D., Schaffer, B., Crane, J.H., 2010. Real-time evapotranspiration-based irrigation scheduling and physiological response in a carambola (Averhoha carambola) orchard. Appl. Eng. Agric., 26: 373-380.

Ko, J., Piccinni, G., 2009. Corn yield responses under crop evapotranspiration-based irrigation management. Agr. Water Manage., 96: 799-808.

Lakso, A.N., 2003. In Apples: Botany, production and uses, Water Relations of Apples, eds Ferree D.C., Warrington I.J., CABI Publishing, Wallingford, UK, pp 167-195.

McCready, M.S., Dukes, M.D., Miller, G.L., 2009. Water conservation potential of smart irrigation controllers on St. Augustine grass. Agr. Water Manage., 96: 1623-1632.

Meron, M., Hallel, R., Peres, M., Bravdo, B., Wallach, R., Gieling, T., 2001. Tensiometer actuated automatic micro irrigation of apples. Acta Horticulturae (562):63-69.

Migliaccio, K.W., Schaffer, B., Crane, J.H., Davies, F.S., 2010. Plant response to evapotranspiration and soil water sensor irrigation scheduling methods for papaya production in south Florida. Agr. Water Manage. 97: 14521460.

Naor, A., Cohen, S., 2003. Sensitivity and variability of maximum trunk shrinkage, solar noon stem water potential, and transpiration rate in response to withholding irrigation from field grown apple trees. HortScience, 38: 547551.

Ojha, T., Misra, S., Raghuwanshi, N.S., 2015. Wireless sensor networks for agriculture: The state-of-the-art in practice and future challenges. Comput. Electron. Agr., 118: 66-84.

Orta, A.H., Erdem, Y., Erdem, T., 2003. Crop water stress index for watermelon. Sci. Hortic-Amsterdam, 98: 121130.

O’Shaughnessy, S.A., Evett, S.R., 2010. Canopy temperature based system effectively schedules and controls center pivot irrigation of cotton. Agr. Water Manage., 97: 1310-1316. 
O’Shaughnessy, S. A., S. R. Evett, P. D. Colaizzi, and T. A. Howell. 2012a. Grain sorghum response to irrigation scheduling with the Time Temperature Threshold method and deficit irrigation. Trans. ASABE, 55(2): 451-461.

O’Shaughnessy, S.A., Evett, S.R., Colaizzi, P.D., Howell, T.A., 2012b. A crop water stress index and time threshold for automatic irrigation scheduling of grain sorghum. Agr. Water Manage. 107: 122-132.

O’Shaughnessy, S.A., Evett, S.R., Colaizzi, P.D., Howell, T.A., 2013. Wireless sensor network effectively controls center pivot irrigation of sorghum. Appl. Eng. Agric., 29(6): 853-864.

O’Shaughnessy, S.A., Evett, S.R., Colaizzi, P.D., 2015. Dynamic prescription maps for site-specific variable rate irrigation of cotton. Agr. Water Manage., 159: 123-138.

Osroosh, Y., Peters, R.T., Campbell, C.S., 2014. Estimating Actual transpiration of apple trees based on infrared thermometry. J. Irrig. Drain. Eng., 10.1061/(ASCE)IR.1943-4774.0000860, 04014084.

Osroosh, Y., Peters, R.T., Campbell, C.S., 2015a. Estimating Potential transpiration of apple trees using theoretical non-water-stressed baselines. J. Irrig. Drain. Eng., 10.1061/(ASCE)IR.1943-4774.0000877, 04015009.

Osroosh, Y., Peters, R.T., Campbell, C., Zhang, Q., 2015b. Automatic irrigation scheduling of apple trees using theoretical crop water stress index with an innovative dynamic threshold. Comput. Electron. Agr., 118: $193-203$.

Osroosh, Y., Peters, R.T., Campbell, C., 2016. Daylight crop water stress index for continuous monitoring of water status in apple trees. Irrig. Sci., 34(3): 209-219.

Palmer, J.W., Giuliani, R., Adams, H.M., 1997. Effect of crop load on fruiting and leaf photosynthesis of 'Braeburn'/M.26 apple trees. Tree Physiol., 17: 741-746.

Paltineanu, C., Septar, L., Moale, C., 2013. Crop water stress in peach orchards and relationships with soil moisture content in a Chernozem of Dobrogea. J. Irrig. Drain Eng., 139(1): 20-25.

Pedro Vaza, C.M., Calboa, A.G., Portob, L.F., Portob, L.H., 2013. Principles and applications of a new class of soil water matric potential sensors: the dihedral tensiometer. Procedia Environ. Sci., 19: 484 - 493.

Peters, R.T., Evett, S.R., 2008. Automation of a Center Pivot Using the Temperature-Time-Threshold Method of Irrigation Scheduling. J. Irrig. Drain Eng., 133(3): 286-291.

Rolston, D.E., Biggar, J.W., Nightingale, H.I., 1991. Temporal persistence of spatial soil-water patterns under trickle irrigation. Irrig. Sci., 12: 181-186.

Romero, R., Muriel, J.L., García, I., Munoz de la Pena, D., 2012. Research on automatic irrigation control: State of the art and recent results. Agr. Water Manage., 114: 59- 66. 
Smith, M., Pereira, L.S., Beregena, J., Itier, B., Goussard, J., Ragab, R., Tollefson, L. Van Hoffwegen, P. (Eds.), 1996. Irrigation Scheduling: From Theory to Practice. FAO Water Report 8, ICID and FAO, Rome.

Stegman, E.C., Schiele, L.H., Bauer, A., 1976. Plant water stress criteria for irrigation scheduling. Trans. ASAE 19: $850-855$.

Stone, K.C., Smajstrla, A.G., Zazueta, F.S., 1985. Microcomputer-based data acquisition system for continuous soil water potential measurements. Soil Crop Sci. Soc. Fla. Proc., 44: 49-53.

Testi, L., Goldhamer, D.A., Iniesta, F. \& Salinas, M. 2008. Crop water stress index is a sensitive water stress indicator in pistachio trees. Irrig. Sci., 26: 395-405.

Thompson, R.B., Gallardo, M., Valdez, L.C., Fernandez, M.D., 2007. Using plant water status to define threshold values for irrigation management of vegetable crops using soil moisture sensors. Agr. Water Manage., 88: 147158.

Thompson, S.J., Armstrong, C.F., 1987. Calibration of the Watermark Model 200 Soil matric potential Sensor. Appl. Eng. Agric., 3(2): 186-189.

Turner, N.C., 1988. Measurement of plant water status by the pressure chamber technique. Irrig. Sci., 9: 289-308.

Upchurch, D.R., D.F. Wanjura, J.J. Burke, and J. R. Mahan. 1996. Biologically-identified optimal temperature interactive console (BIOTIC) for managing irrigation. U.S. Patent No. 5539637.

Varble, J.L., Chávez, J.L., 2011. Performance evaluation and calibration of soil water content and potential sensors for agricultural soils in eastern Colorado. Agr. Water Manage., 101: 93- 106.

Vellidis, G., Tucker, M., Perry, C., Kvien, C. Bednarz, C., 2008. A real-time wireless smart sensor array for scheduling irrigation. Comput. Electron. Agr., 61: 44-50.

Wanjura, D.F., Upchurch, D.R., Mahan J.R., 1992. Automated irrigation based on threshold canopy temperature. Trans. ASAE, 35(1):153-159.

Wanjura, D.F., Upchurch, D.R., Mahan, J.R., 1995. Control irrigation scheduling using temperature-time thresholds. Trans. ASAE 38, 403-409.

Wanjura, D.F., Upchurch, D.R., 1997. Accounting for humidity in canopy-temperature-controlled irrigation scheduling. Agr. Water Manage., 34: 217-23.

Wang, D., Gartung, J., 2010. Infrared canopy temperature of early-ripening peach trees under postharvest deficit irrigation. Agr. Water Manage., 97(11): 1787-1794. 
Zhang, Q., Pierce, F.J. (Eds.), 2013. Agricultural Automation: Fundamentals and Practices (1st Ed.). CRC Press, Boca Raton, FL, 411 pp.

Zotarelli, L., Scholberg, J.M., Dukes, M.D., Mũnoz-Carpena, R., 2009. Tomato yield, biomass accumulation, root distribution and irrigation water use efficiency on a sandy soil, as affected by nitrogen rate and irrigation scheduling. Agr. Water Manage., 96: 23-34. 